\title{
Going Nuclear: Rule Manipulation and Judicial Nomination Efficacy
}

\author{
Corey Bopp \\ Department of History, Politics, and Law, California University of Pennsylvania, California, PA, USA \\ Email: BOP3192@calu.edu
}

How to cite this paper: Bopp, C. (2019). Going Nuclear: Rule Manipulation and Judicial Nomination Efficacy. Open Journal of Political Science, 9, 687-702.

https://doi.org/10.4236/ojps.2019.94042

Received: July 4, 2019

Accepted: October 28, 2019

Published: October 31, 2019

Copyright $\odot 2019$ by author(s) and Scientific Research Publishing Inc. This work is licensed under the Creative Commons Attribution International License (CC BY 4.0).

http://creativecommons.org/licenses/by/4.0/

\begin{abstract}
The growing number of federal judicial vacancies impacts judiciary's ability to efficiently resolve litigation. This impact warrants an investigation of any factor that has the potential to affect the number of vacancies. This paper examines three factors in relation to the federal judicial nomination process. The examination is performed through a statistical analysis of judicial confirmation rates in relation to the elements. The elements of principal concern are: the National Labor Relations Board v. Noel Canning Supreme Court ruling, Harry Reid's 2013 removal of the 60 vote requirement to invoke cloture on a nomination, and the mutable power assigned to blue slips. The data shows a complete stoppage of attempted recess appointments following the Supreme Court ruling. Due to calculated scheduling of pro forma sessions by Congress, there have been no recesses that exceed the necessary time frame established by the Supreme Court to make a recess appointment. The removal of the 60 vote requirement to invoke cloture resulted in a $267 \%$ increase in confirmed nominees during the 113th Congress. This increase was not sustained through a divided Senate and executive, and the 115th Congress's confirmation rate does not indicate the trend will continue. However, the data set is currently insufficient to make a final judgement on its impact. Blue slipping, as an uncodified procedure, has a variable influence on judicial nominees. A correlation between the chair of the Senate Judiciary Committee and nominee ideology suggests that chairmen are more likely to expedite the appointment of nominees with ideologies similar to their own.
\end{abstract}

\section{Keywords}

Judicial Nominations, Nuclear Option, Recess Appointments, Blue Slip, Judiciary Committee

\section{Introduction}

The partisan divide in American politics is an ever-present and increasingly ar- 
duous task for policy makers to traverse. This divide has contributed to members of the legislature resorting to obstructionist tactics. These tactics are fundamentally obstructionist insofar as they are designed to prevent the proliferation of the opposing party's policy and ideology-as opposed to directly advancing their own. This practice contributed to the 112th and 113th Congresses being two of the least productive congressional sessions in American history (Farina \& Metzger, 2015). Political quarrels have been commonplace in the legislature, but they are now beginning to impact the judiciary. Unfilled seats on the bench have become the norm-one in eight Article III judgeships are now unoccupied (United States Courts, 2019). The judiciary is unique in that its officials are not elected; they are instead nominated and depend on the efficiency of the legislature to operate. This nominative mechanism leaves the judiciary vulnerable to manipulation by ideologically motivated elected officials. For this reason, an analysis of how the federal judicial nomination process has been affected by recent rule and procedure changes is warranted. This analysis will be done by examining specific instances of rule and procedure alterations. The examination will include a statistical analysis of judicial nominations before and after the November 2013 implementation of the nuclear option, a breakdown of recess appoints before and after the National Labor Relations Board v. Noel Canning (2014) Supreme Court decision, and case studies examining the fluctuating power of blue slips. This investigation will allow one to determine the effects these changes have had on judicial nominations and attempt to predict their future ramifications.

\section{Literature Review}

A review of the literature concerning federal judicial nominations and contemporary rules and procedures can be broken down into four categories: a broad overview of judicial nominations, blue slips and their historical impact on nominees, an overview of recess appointments, and the state of the nuclear option. The overview of judicial nominations is designed to document both the process a nominee must go through to be confirmed and the progression of the process to its current state. The section concerning blue slips is aimed to describe the origination of blue slips and chronicle their changing power in relation to former chairs of the Senate Judiciary Committee. The overview of recess appointments is designed to prelude the National Labor Relations Board v. Noel Canning (2014) Supreme Court decision. The section on the state of the nuclear option is intended to describe the rule change and discuss common views on its impact and constitutionality. These groupings can adequately survey the federal judicial confirmation process by outlining the historical progression, the rules involved in the process, and the recent changes in the confirmation process.

\subsection{History of Federal Judicial Nominations}

The judicial confirmation process is the path that every Article III judicial no- 
minee must go through in order to ultimately be confirmed as a federal judge. The appointment power is vested in the President by the United States Constitution, "[The President] shall nominate, and by and with the advice and consent of the Senate, shall appoint ... judges of the Supreme Court, and all other officers of the United States, whose appointments are not herein otherwise provided for, and which shall be established by law (U.S. Const. art. II, $₫ 2$.)”. The nominative process begins with a nomination by the president, the nominee is then heard by the Senate Judiciary Committee, and then by the entirety of the Senate. Prior to the nominee's announcement, the President will usually consult with senators in the area that the judge will serve. During the Senate Judiciary Committee's hearing, the nominee's past is investigated and witnesses supporting and opposing the nominee present their opinions. After the Senate Judiciary Committee's hearing the nominee is sent to the Senate with the committee's positive, negative, or absent recommendation. The nomination can be stopped, or withdrawn by the executive, at any step in the process. Once the nominee reaches the Senate floor the nomination can be voted upon; with a simple majority confirming the nominee to the judgeship.

Despite the seemingly concise nature of the process, a nominee can be held at any point for extended periods of time-this is what causes the long drawn out nominations that have recently become commonplace. The chair of the Senate Judiciary Committee plays a major role in the speed in which a nominee is heard or confirmed, some confirmations take only days, while others take months or even years (Binder \& Maltzman, 2002). As ideological differences between the chair and the president increase, as does the time to confirmation (Binder \& Maltzman, 2002). Judicial nominations to lower courts were formerly devoid of serious conflict until the past few decades (Binder \& Maltzman, 2002). Many nominations to the lower courts, the US District Courts and the US Courts of Appeals, were formerly confirmed through vocal votes that were assumed near unanimous due to senatorial courtesy (Epstein \& Segal, 2005). This vocal vote practice has become more common since November 2013. Epstein and Segal assert that the phenomenon of contention over lower court nominations began in the 1980s, when both parties began to see the impact that the lower courts have on setting legal precedents in America (2005). It has been argued that senators are internally incentivized to expedite the confirmation of judges with ideologies similar to themselves and slow to confirmation of their ideological counterparts (Binder \& Maltzman, 2002). Nonetheless, some scholars note that ideological concerns sometimes trump partisan political concerns (Epstein \& Segal, 2005). These scholars cite multiple instances of conservative democrats crossing the aisle to stop the nomination of a liberal judge, as well as the reverse (Epstein \& Segal, 2005). However, a majority of these instances occurred greater than ten years ago (Epstein \& Segal, 2005). An examination of judicial nominations from 1981-2013 shows nearly a $10 \%$ decrease in the overall percentage of nominees confirmed (Rutkus et al., 2014). Furthermore, in this time period, every administration except the George W. Bush administration experienced a growth in 
overall judicial vacancies (Brown, 2013). The trend of increasing vacancies has persisted through the Obama administration and holds true through the first two years of the Trump presidency (United States Courts, 2019).

\subsection{Blue Slips}

The blue slip is an opportunity for a senator to express his or her approval, disapproval, or abstention from judging a judicial candidate that has been nominated to a position in the senator's state (Black et al., 2011). The blue slip is a non-codified congressional procedure. This is important because it makes blue slips an informal procedure; allowing the chair of the Senate Judiciary Committee to decide the power of the slip (Sollenberger, 2010). Senators that do not belong to the president's party are more likely to employ negative blue slips, while senators from the president's party typically return positive slips (Black et al., 2011). Blue slips evolved from verbalized senatorial courtesy. The evolution resulted in a tangible way in which a senator's opinion, or lack thereof, of a candidate could be expressed (Sollenberger, 2010). Due to the variable power of the blue slip, the periods of influence can be segmented by the chairs of the Judiciary Committee that either started or ended trends of power.

The blue slip originated in 1917 and did not act as a veto, instead the slips acted as recommendations. In 1956, Senator James Eastland gave the blue slip true veto power and stopped any nomination that did not receive two positive blue slips (Sollenberger, 2010). This trend ended in 1979 when Senator Edward Kennedy returned the blue slip to its former position as only a suggestion to other senators from the home-state senator (Sollenberger, 2010). In 1987, when Senator Joe Biden became chair of the Senate Judiciary Committee, he took a pragmatic approach to blue slips (Sollenberger, 2010). A negative blue slip acted as a veto only if Senator Biden felt it was not being used to obstruct the nomination of a qualified candidate (Sollenberger, 2010). In 2001, Senator Orrin Hatch began ignoring both positive and negative blue slips entirely and proceeded with nominations regardless of the blue slip that was returned (Sollenberger, 2010). In 2006, and until 2015, a negative or unreturned blue slip acted as a veto and stopped all progress for a nomination (Sollenberger, 2010; Black et al., 2011). Under Senator Chuck Grassley, the blue slip was at first given veto power and later that power was lessened after President Obama left office. Mitchell Sollenberger asserts in his work that due to partisan and ideological concerns chairmen take the position that most benefits their party at the time (Sollenberger, 2010).

\subsection{Recess Appointments}

A recess appointment is an appointment by the executive while Congress is not in session. The appointee assumes the responsibilities of the position he or she was appointed to, but must later be confirmed before the end of the congressional session. Recess appointments are sometimes viewed as the executive's attempt to circumvent Congress's advice and consent power while Congress in not in session (Hogue, 2017). Due to this characterization, recess appointments have 
a high potential for abuse and must be closely monitored (Graves \& Howard, 2010). There is a correlation between a high number of executive orders and attempted recess appointments (Graves \& Howard, 2010). Both of these actions show an attempt to bypass congressional powers and may be indicative of an executive overstepping its bounds of power. Both attempted and confirmed recess appointments have declined since 2007; President George W. Bush attempted 171 total recess appointments, President Obama attempted 32 total recess appointments, and President Trump has attempted none in the first half of his presidency (Hogue, 2017). The recent drop in attempted recess appointment may be due to the 2014 precedent setting Supreme Court decision, National Labor Relations Board v. Noel Canning (2014). Justice Stephen Breyer delivered the opinion of the Court and stated, "in light of historical practice... a recess less than 10 days is presumptively too short to fall within the [Recess Appointment] Clause" (National Labor Relations Board v. Noel Canning, 2014). This ruling quantified the time period necessary for an appointment to be made, prior to the ruling the standard was not established. The power to make such appointments is granted to the President by the United States Constitution's recess appointment clause, "The President shall have power to fill up all vacancies that may happen during the recess of the Senate, by granting commissions which shall expire at the end of their next session (U.S. Const. art. II, $\$ 2) ”$.

\subsection{The Nuclear Option}

The nuclear option is the name given to the change in parliamentary procedure that allows the Senate to override the sixty vote requirement to invoke cloture and elude a filibuster by the opposing party (Heitshusen, 2017). After the rule change, only a simple majority is required to end debate on a nominee, thus placing more power in the hands of the majority party (Dauster, 2016). This change was proposed by Senator Harry Reid in November 2013 and, at the time, the change applied only to executive branch nominations and judicial appointments to all courts except the Supreme Court. In April 2017, Senator Mitch McConnell extended the change to include Supreme Court nominations.

This rule change was brought about by the increase in obstructionist tactics being used by both parties; particularly the minority party during the 113th Congress (Dauster, 2016). In recent history Congress has taken an adversarial stance during judicial confirmation proceedings (Gerhardt \& Painter, 2017). This means that senators have been attempting to halt the progress of the opposing party, instead of acting to fill judicial vacancies with qualified candidates. Christian Boyd, Michael Lynch, and Anthony Madonna theorized that this change in rules would result in more ideologically extreme judges being confirmed. They measured the ideology of judges by quantifying their ideology numerically on the basis of past rulings. Upon examination of confirmed judges before and after the rule change, the researchers determined that there was not an increase in the ideological extremeness of newly appointed judges (Boyd et al., 2015). The researchers did note, however, a significant decrease in confirma- 
tion time and an increase in the percentage of nominees that were confirmed (Boyd et al. 2015). This change in rules allows for the executive to more effectively combat the growing problem of judicial vacancies (Dauster, 2016).

Some scholars do not feel that the change is for the better. Mark Owens asserts that the nuclear option rescinds much of the minority's former power (2018). James Wallner claims that the judicial filibuster is important to the constitutional doctrine of separation of powers (2016) Furthermore, the judicial filibuster is necessary if the Senate is to serve the role envisioned by the Framers of the Constitution, so the nuclear option undermines the original intent of the constitution (Wallner, 2016). The assertion that the nuclear option is unconstitutional has not yet been formally pursued. Generally, by removing power from the minority party the country is closer to being exploited by a majority party that chooses to aggressively pursue its ideology (Wallner, 2016; Owens, 2018).

\section{Research Methods Employed}

The previously described examination will be conducted by compiling judicial nomination data, judicial confirmation data, recess appointment data, and case studies involving the use of blue slips. The data contains information pertaining to judicial nominations and confirmations during the 111th, 112th, 113th, 114th, and 115th Congresses (Senate Committee on the Judiciary, 2019). These Congresses were chosen due to their temporal proximity and relation to the 2013 nuclear option. From January 3rd, 2009, to January 3rd, 2019, these Congresses were in session consecutively. Once the data were compiled the number of nominees and confirmed judges were entered into the data visualization program Tableau. Once visualized, the congressional sessions were partitioned in relation to the 2013 implementation of the nuclear option. Conclusions concerning the immediate and future impact of the nuclear option were drawn from these visualizations using descriptive and predictive analysis. Trends in the data were identified and explanatory conclusions were posited. Then, the data were partitioned on the basis of either a united senate and executive or one that was divided. Conclusions were again drawn through the use of descriptive and predictive analysis. Trends in the data were identified and explanatory conclusions were posited. The percentage of nominees that were confirmed under each administration was compiled to identify possible outliers. A percentage was used instead of gross confirmation numbers in order to account for varying tenure lengths as president.

Data was gathered in order to track the number of recess appointments made and the number of opportunities the executive has had to make such an appointment. This data was drawn from the United States Government's Publishing Office's publication of the Senate's Calendar of Business from January 1st, 2013, until January 3rd, 2019. These dates were chosen due to their historical relation to the National Labor Relations Board v. Noel Canning Supreme Court ruling (2014). The scheduling data were transcribed into Microsoft Excel so that 
it could be interpreted by the statistical computing software R. The scheduling data were entered into the software environment $\mathrm{R}$ in order to identify periods of recess exceeding five days or ten days.

Case studies will be used in investigating the power of blue slips, because the contextual elements of each case are more descriptive and allow for more to be extrapolated from each instance than statistics alone. These case studies will include the confirmations of Judge David Stras, Judge Michael Brennen, Judge Ryan Bounds, and the return of nominee Donald K. Schott (Library of Congress, 2018). These cases will be compared to the previous precedent set by former chair of the Senate Judiciary Committee Chuck Grassley, during the prior administration - as well as compared against the precedents sent by prior chairs of the Senate Judiciary Committee.

\section{Results and Discussion}

During the 113th Congress, there was a significant increase in judicial confirmations immediately following the November 13th, 2013, implementation of the nuclear option. This increase can be seen below in Table 1 (Senate Committee on the Judiciary, 2019). This increase did not maintain through the 114th Congress (Senate Committee on the Judiciary, 2019). This may be attributed to the 114th Congress gaining a Republican majority while the executive was still held by a Democrat. The judicial confirmation statistics from the 111th Congress to the 115th Congress were compiled and can be seen below in Table 2 (Senate Committee on the Judiciary, 2019). The 111th Congress saw 111 total nominations, 60 that were confirmed, 50 that were returned to the president, and one that was withdrawn by the president (Senate Committee on the Judiciary, 2019). The 112th Congress saw 154 total nominations, 111 that were confirmed, 40 that were returned to the president, and three that were withdrawn by the president (Senate Committee on the Judiciary, 2019). The 113th Congress saw 204 total

Table 1. Source: Senate Committee on the Judiciary (2019). 113th congress before and after the nuclear option: confirmations to lower courts.

\begin{tabular}{ccc}
\hline Court & Pre-November 13th 2013 & Post-November 13th 2013 \\
\hline Court of Appeals & 9 & 14 \\
District Courts & 27 & 82 \\
Total Confirmed & 36 & 96 \\
\hline
\end{tabular}

Table 2. Source: Library of Congress (2018). Result of judicial nominations in the 111th, 112th, 113th, 114th, and 115th congresses.

\begin{tabular}{cccccc}
\hline Result & \multicolumn{1}{c}{ 111th Congress } & 112th Congress & 113th Congress & 114th Congress & 115th Congress \\
\hline Confirmed & 60 & 111 & 134 & 20 & 85 \\
Returned & 50 & 40 & 69 & 52 & 99 \\
Withdrawn & 1 & 3 & 3 & 0 & 1 \\
\hline
\end{tabular}


nominations, 132 that were confirmed, 69 that were returned to the president, and three that were withdrawn by the president (Senate Committee on the Judiciary, 2019). The nuclear option was instituted on November 13th, 2013, nearly splitting the 113th congressional session into two equal parts; one pre-nuclear option and one post. Within the 113th Congress, prior to November 13th, 2013, there were 36 total appointments, after this date there were 96 total appointments (Senate Committee on the Judiciary, 2019). This constituted a $267 \%$ overall increase in judicial confirmations after the rule change. These statistics are visually represented above in Table 1 . The 114th Congress, was the only divided Senate and executive of the aforementioned sessions. This session saw 72 total nominations, posting 20 total confirmations, 52 nominations returned to the president, and no nominations withdrawn by the president (Senate Committee on the Judiciary, 2019). The 114th Congress was the least active of the examined congresses. The 115th Congress had 185 total nominations, 85 total confirmations, 99 nominations returned to the president, and one nomination withdrawn by the president (Senate Committee on the Judiciary, 2019). These statistics from the above-mentioned congressional sessions are visually represented below in Table 2.

During the 115th Congress, of the 85 nominees that were voted upon, 100\% were confirmed (Senate Committee on the Judiciary, 2019). Further, of the 112 candidates that reached a position on the Senate's executive calendar during the entirety of the 115th Congress, 85 were confirmed, 27 were not voted upon before the end of the session, and thus returned to the president (Library of Congress, 2018). Of those returned, nearly all were resubmitted at the onset of the 116th Congress (Library of Congress, 2018).

The failure rate for nominations to Federal District Courts from 1981-2014 is 23.7\%, while the failure rate for Circuit Courts during this time is even higher at $40.8 \%$ (O'Connell, 2015). This rate of failure is constituted by nominees either being withdrawn by the president or returned to the president by the Senate, but this percentage may be inflated as it does not account for nominees returned to the president, later re-nominated, and ultimately confirmed. The confirmation percentage through the first term of the previous six administrations has been relatively consistent prior to the most recent administration. President Reagan proposed 182 nominees and had 163 confirmed earning an 89.6\% confirmation percentage, the highest through the first term of the previous six administrations (Brown, 2013). President H. W. Bush nominated 248 individuals and had 192 confirmed, netting a $77.4 \%$ confirmation percentage, the second lowest through the first term of the previous six administrations (Brown, 2013). President Clinton nominated 239 people to judgeships and 200 of them were confirmed, totaling an $83.7 \%$ confirmation percentage (Brown, 2013). President G. W. Bush offered 231 nominees, 205 of which were confirmed and achieved an $88.7 \%$ confirmation percentage. President Obama proposed 215 nominees, and 173 that were ultimately confirmed, earning an $80.5 \%$ confirmation percentage (Brown, 2013). Through the first half of President Trumps first term he has proposed 185 
nominees, 85 of which have been confirmed, earning the lowest confirmation percentage at $45.9 \%$ (Library of Congress, 2018). It is notable that many of the candidates returned at the conclusion of the 115th Congress have been resubmitted during the 116th Congress (Senate Committee on the Judiciary, 2019).

The number of recess appointments over the past 4 administrations has dramatically dropped. The Clinton administration made 139 recess appointments, 95 to full-time positions and 44 to part-time, the G. W. Bush administration made 171 recess appointments, 99 to full-time and 72 to part-time, the Obama administration made 32 recess appointments, all to full-time positions (Hogue, 2017). Through the first two years of the Trump administration no recess appointments have been made (Library of Congress, 2018). This lack of recess appointments by the latest administration may not be for lack of desire to do so, but instead for lack of opportunity. On June 26th, 2014, the Supreme Court ruled in National Labor Relations Board v. Noel Canning (2014), "We therefore conclude, in light of historical practice, that a recess of more than 3 days but less than 10 days is presumptively too short to fall within the [Recess Appointments] Clause". Since the date of this precedent setting ruling, there have been 10 recesses of greater than 10 days, none of which occurred after January 1st, 2016 (U.S. GPO, 2018). To put this into perspective between January 1st, 2016, and January 1st, 2013, there were 17 recesses of greater than 10 days (U.S. GPO, 2018). Between January 1st, 2016 and January 3rd, 2019, there have been no instances of recesses exceeding 10 days (U.S. GPO, 2018). These statistics are visually represented in Figure 1. In this time period however, there have been 174 instances of recess fewer than 5 days (U.S. GPO, 2018). The Senate usually takes a prolonged recess during the months of August and December. From 2013 to 2015, there was at least one recess of greater than 10 days every December and August, yet this has not been the case recently (U.S. GPO, 2018). In August and December of 2016, 2017, and 2018, the Senate has scheduled pro forma sessions every Tuesday and Friday, as to avoid breaks of longer than 10 days (U.S. GPO, 2018).

The use of the blue slip is difficult to quantify due to the subjective nature of

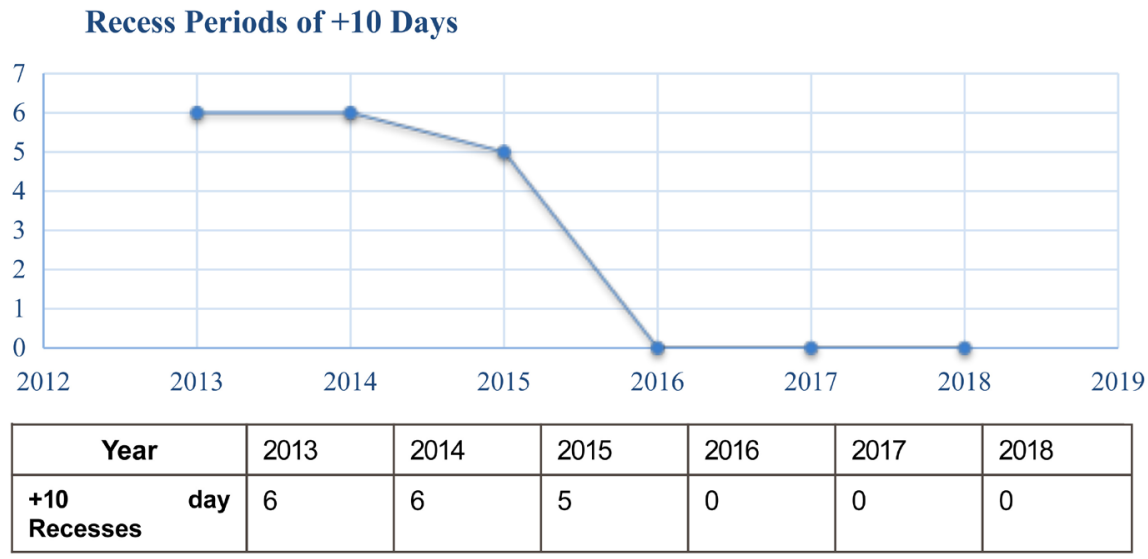

Figure 1. Source: United States government's publishing office (2019). 
its power, so case studies will be employed to allow for a better understanding of their use. Barry J. McMillion a National Government Analyst stated in a Congressional Research Service Report, "During the Obama presidency, the policy of... Senator Chuck Grassley was to preclude consideration of a U.S. circuit or district court nomination by the committee if the nomination did not receive two positive blue slips from the nominee's home state senators" (2017). During the 114th Congress, in which Senator Chuck Grassley was the head of the Senate Judiciary Committee, 9 nominees had returned either a negative blue slip or withheld a blue slip. Of these nominees none were ultimately confirmed (McMillion, 2017). This includes the January 12th, 2016, nomination of Donald K. Schott to the United States Court of Appeals Seventh Circuit (Library of Congress, 2018). This nomination was blocked following a negative blue slip from Republican Senator Ron Johnson (Alliance for Justice, 2016). The political affiliation of Senator Johnson is important because, as Mitchell Sollenberger notes, the chair of the Senate Judiciary Committee typically takes the stance towards blue slips that is the most advantageous to his or her political ideology at that time (Sollenberger, 2010). With the change in administration in 2017, Senator Grassley maintained his positon as head of the Senate Judiciary Committee. He did, however, alter the power allotted to blue slips. Senator Grassley stated in a November 13, 2017, Senate floor speech, "the blue slip isn't supposed to allow the unilateral veto of a nominee... So, I won't let senators abuse the blue slip to block qualified nominees". This change is evident in the January 8th, 2018, nomination of Michael B. Brennan to the United States Court of Appeals Seventh Circuit (Senate Committee on the Judiciary, 2019). Following this nomination, a negative blue slip was returned by Senator Tammy Johnson in regards to Brennan's nomination (Alliance for Justice, 2018). However, despite this negative blue slip Brennan's nomination continued and was ultimately confirmed on May 10th, 2018 (Senate Committee on the Judiciary, 2019). This change in stance is also made evident by the confirmation of Judge David Strass, despite Minnesota Senator Al Franken's failure to return a blue slip (Alliance for Justice, 2018). Senator Al Franken was a Democratic senator, so his ideology may have conflicted with Republican Senator Chuck Grassley's. Despite both home senators, Democrats Ron Wyden and Jeff Merkley, returning negative blue slips regarding his nomination (Senate Committee on the Judiciary, 2019; Alliance for Justice, 2018). Again, as senators ideologically opposed to former Chairman Grassley, experts like Sollenberger would assert ideological motives. It is impossible to assign specific motives to the former chair, but in these cases and others, more weight is given to blue slips provided by senators with similar political affiliations to the former chair.

\section{Analysis}

Despite the low number of judicial confirmations through the first half of the current administration (Library of Congress, 2018), the effect of the nuclear op- 
tion is evident. There was a $267 \%$ increase in judicial confirmations immediately after the reform took place. The timing of the original implementation is fortunate because it nearly splits the 113th Congress in half. There was 315 days prior to the employment of the reform, and 415 days after. These periods comprise $43 \%$ and $56 \%$ of the congressional period respectively, however, there were $27 \%$ of the total appointments prior to the reform, and after there was $73 \%$ of the total appointments (Library of Congress, 2018). The reduction in total confirmations and the reduction in confirmation efficiency in the 114th Congress can be explained in part by the divided executive and Senate. The nuclear option enables the majority party in the Senate to expedite confirmations, if the majority party does not support the nominee then the effect is null. The reason the effect of the nuclear option was so apparent within the 113th Congress was because the executive and Senate were united. One may contend that the influx of nominations during the 113th Congress was an outlier and point to the relatively small number of confirmations thus far by the Trump administration. This is a valid point and it appears that the current administration is not on pace with its predecessors, but it is impossible to make a definitive judgement until the current presidential term ends. To quantify the trend, the 111th, 112th, 113th, and 114th Congresses averaged 81.25 confirmations per session, just under the 115th Congress's 85 confirmations. However, when comparing Congresses with a united Senate and executive, excluding the 114th Congress, the average rises to 101.667 confirmations per session. The latter number may be a more apt comparison due to the unusually low confirmation numbers posted by the 114th Congress.

To use the inefficiency of this administration as an attack on the impact of the nuclear option as a whole may be misguided. The underlying reasons may be more aligned with the president's inexperience in government or polarizing nature. The current executive has had no experience in either the Senate or the House and this may harm his attempts to push nominees through the confirmation process. The president ran on a platform that utilized harsh and aggressive diction, some scholars note this as the reason many politicians have taken strong stances either for or against his administration (Mason, 2018; Ostiguy \& Roberts, 2016). This polarization has caused some congressman with similar ideologies to take issue with him or his judicial nominees. Despite this, the administration has earned a $100 \%$ confirmation rate of nominees once they reach the Senate floor for a final vote. Given this statistic the problem seems to be more so getting the nominees to that point in the confirmation process. The 116th Congress may serve as a barometer for the accuracy of the claim that the executive's inexperience is deflating the confirmation rate.

Opportunities for recess appointments, as seen in Figure 1, have dramatically declined since the National Labor Relations Board v. Noel Canning (2014) ruling was delivered. This is possibly due to the Senate's desire to prevent the executive from circumventing the nomination process. The absence of recesses greater than 10 days may not be an accident, and is supported by the increase in recesses 
of less than 5 days. This is made more apparent by the Senate's careful use of pro forma sessions to avoid long recesses (U.S. GPO, 2018). These statistics seem to decisively indicate that the Senate has altered its schedule in accordance with National Labor Relations Board v. Noel Canning (2014) ruling in order to prevent recess appointments. What remains to be determined is if this is circumstantial due to the current administration's perceived propensity to act unilaterally or if this practice will persist through future presidencies.

Given the presented case studies one can see a clear shift in the former chair of the Senate Judiciary Committee, Senator Chuck Grassley. While under the previous administration Senator Grassley treated a negative or unreturned blue slip like a veto, yet, once the change in administration occurred, Senator Grassley adjusted the weight he gave to the blue slip (McMillion, 2017). Senator Grassley blocked nine nominees from continuing through the nomination process while he was chair of the Senate Judiciary Committee during the 114th Congress (McMillion, 2017). A liberal judge was blocked by a negative blue slip from a Republican senator under a Democratic administration. Later, a conservative judge was allowed to progress despite a negative blue slip from a Democratic senator under a Republican administration. The classification of liberal or conservative is based upon the judges self-professed stances, prior rulings, and alignment with political entities. These judges were elected to the same position, and Senator Chuck Grassley was Chair of the Senate Judiciary Committee in both cases. The most plausible explanation is asserted made by Mitchell Sollenberger in his 2010 article, "The Blue Slip: A Theory of Unified and Divided Government, 1979-2009", that the Republican chairmen took the position that most benefited his party at the time. During the 115th Congress Senator Grassley allowed multiple nominees with negative or unreturned blue slips to progress through the nomination process (Library of Congress, 2018; Alliance for Justice, 2018). The power of the blue slip appears to be directly related to the political affiliation of the executive and the Chair of the Judiciary Committee. In effect, senators that share their affiliation with both of the aforementioned offices have a greater respect paid to their blue slips, while those that do not share an affiliation are often ignored.

\section{Conclusion}

Of the changes examined, the most effectual appears to be the decrease in recess appointments following the National Labor Relations Board v. Noel Canning (2014) Supreme Court ruling. There has since been no recess appointments made and the opportunities to do so have been minimal. The most recent recess appointments occurred on January 4th, 2012, and three of the four appointments made at that time were the appointments that triggered the precedent setting case (CRS, 2017). Since the decision was issued, there have been fewer than ten recesses of greater than ten days. It seems to be the case that this is due to the guidelines set forth by the ruling-which restricts recess appointments during 
recesses of fewer than ten days. This trend may continue, but some may argue the reason for its current persistence is the perceived likelihood of the current administration to abuse the recess appointment clause. This assertion is impossible to quantify or test at this time. However, if the trend changes after a shift in administration the assertion may have merit and this drought of appointments can be viewed as an anomaly.

The November 2013 implementation of the nuclear option presents conflicting data. During the 113th Congress and immediately following the enactment, there was a massive increase in appointments (Library of Congress, 2018). This may have been facilitated by a united executive and Senate. In the following Congress the executive and Senate were divided. This may be why the 114th Congress was the least productive Congress, regarding judicial nominations, since 1952 (Library of Congress, 2018). The most recent completed Congress, posted middling confirmation numbers despite a united executive and Senate (Library of Congress, 2018). It could be argued that this indicates that the nuclear option will prove inefficacious as time passes, but this overlooks other viable explanations. The current administration is unique insofar as the executive has neither a political nor military background, and has caused extreme polarization between the major parties. These qualities make a case that the current data will prove to be anomalous. If this proves true, the 113th and 114th Congresses will support the assertions made by Mark Owens and James Wallner that the power of the minority party has weakened and the majority expanded $(2018,2016)$. This shift in power has the potential, as studied by Christian Boyd, Michael Lynch, and Anthony Madonna, to result in more ideologically extreme judges. This is because the minority party can longer stop an extreme judge from being confirmed by invoking unlimited debate. Despite this, their research concluded that the nuclear option did not result in significantly more ideologically extreme nominees (Boyd et al., 2015). This research does not mean that a future administration will not pursue more ideologically extreme judges only that, during the period studied, this was not the case. It is possible that the constitutionality of the nuclear option will be challenged in court someday-on the grounds that the mitigation of the minority party's power is not fitting with the intent of the constitution.

The final examined procedure was blue slipping. Due to the uncodified nature of blue slipping, it is difficult to develop a conclusive determination of its current or future power. The power of the blue slip is subjective and largely determined by the chair of the Senate's Judiciary Committee. During the 114th Congress, former Chairman of the Senate Judiciary Committee, Senator Chuck Grassley, allowed blue slips to effectively veto the nomination of judges that did not match his political ideology (McMillion, 2017). For the duration of the 115th Congress, Senator Grassley overlooked the previous precedent that he set and ignored many blue slips in order to advance the nominations of judges that shared his ideology (Library of Congress, 2018; Alliance for Justice, 2018). By ignoring the precedent set during the 114th Congress, Senator Grassley demonstrated that the 
power of the blue slip is subjective and that it is able to be changed at the chair's discretion. This supports Mitchel Sollenberger's theory that the chair will take the position regarding blue slips that most benefits their party at that time (Sollenberger, 2010).

The biggest issues regarding the judicial nomination process are nominating quality judges and filling vacancies quickly and efficiently. The Obama administration inherited fifty-four vacancies and the Trump Administration inherited one hundred and three (Brown, 2013; O'Connell, 2015; United States Courts, 2019). At the conclusion of the 115th Congress there were one hundred and nine vacancies (United States Courts, 2019). There are eight hundred and seventy Article III judgeships-one in every eight positions, are vacant (United States Courts, 2019). This hinders the efficacy of the judicial branch as a whole. Of the procedures examined, all have the potential to exacerbate the vacancy problem. Even when the Senate and executive are divided, the judicial branch should be able to operate. Absent significant changes, this would require unprecedented bipartisan cooperation between party leadership.

Further research that could advance the work done in this project or ameliorate some of the identified issues includes: an examination of policy changes that may remedy the judicial vacancy issue; continued monitoring and analysis of judicial confirmation efficiency; further examination of ideological extremity of new judicial candidates like that done by Boyd, Lynch, and Madonna (2015); and a case study of the power given to blue slips by new Chair of the Senate Judiciary Committee, Senator Lindsay Graham. As stated before, the issue of judicial vacancies is the largest facing the judicial branch and, at the moment, a resolution is unlikely. By continuing to observe judicial confirmations, one can determine whether the current administration's confirmation rate is an anomaly or if even a united Senate and executive will struggle to push nominees through in the future. By continuing the study of Boyd et al. (2015), one will be able to quantify and notice an executive attempting to radically shift the average ideology of the judiciary. Further case studies will help to verify the validity of Sollenberger's assertion regarding the motives of Chairs of the Senate Judiciary Committee.

\section{Conflicts of Interest}

The author declares no conflicts of interest regarding the publication of this paper.

\section{References}

Alliance for Justice (2016). The Judges of the United States Court of Appeals for the Seventh Circuit. https://www.afj.org

Alliance for Justice (2018). Blue Slip Status for Pending Judicial Nominations. http://www.afj.org

Binder, S. A., \& Maltzman, F. (2002). Senatorial Delay in Confirming Federal Judges, 
1947-1998. American Journal of Political Science, 46, 190-199.

https://doi.org/10.2307/3088422

Black, R. C. et al. (2011). Obstructing Agenda-Setting: Examining Blue Slip Behavior in the Senate. The Forum, 9, 1-15. https://doi.org/10.2202/1540-8884.1476

Boyd, C. L., Lynch, M. S., \& Madonna, A. J. (2015). Nuclear Fallout: Investigating the Effect of Senate Procedural Reform on Judicial Nominations. The Forum, 13, 623-641. https://doi.org/10.1515/for-2015-0042

Brown, M. C. (2013). Federal Judicial Vacancies: Analyses, Implications, and Trends. Hauppauge, NY: Nova Science Publishers, Inc.

Congressional Research Service (2017). Recess Appointments Made by President Barack Obama (CRS Report No. R42329).

https://www.everycrsreport.com/files/20170907_R42329_7788139e1c21c70ac7500a821f $172 \mathrm{e} 72835 \mathrm{e} 97 \mathrm{df} . \mathrm{pdf}$

Dauster, W. G. (2016). The Senate in Transition or How I Learned to Stop Worrying and Love the Nuclear Option. New York University Journal of Legislation \& Public Policy, 19, 631-683.

Epstein, L., \& Segal, J. A. (2005). Advice and Consent: The Politics of Judicial Appointments. Oxford: Oxford University Press.

Farina, C. R., \& Metzger, G. E. (2015). Introduction: The Place of Agencies in Polarized Government (pp. 1-50). Legal Studies Research Paper Series. https://doi.org/10.2139/ssrn.2695419

Gerhardt, M. J., \& Painter, R. W. (2017). Majority Rule and the Future of Judicial Selection. Wisconsin Law Review, 2, 263-284.

Graves, S. E., \& Howard, R. M. (2010). Ignoring Advice and Consent? The Uses of Judicial Recess Appointments. Political Research Quarterly, 63, 640-653. https://doi.org/10.1177/1065912909333129

Heitshusen, V. (2017). Senate Proceedings Establishing Majority Cloture for Supreme Court Nominations: In Brief (pp. 1-4). Congressional Research Service (April).

Hogue, H. B. (2017). Recess Appointments Made by President Barack Obama (pp. 1-15). Congressional Research Service (September).

Library of Congress (2018). https://congress.gov

Mason, L. (2018). Uncivil Agreement: How Politics Became our Identity. Chicago, IL: The University of Chicago Press. https://doi.org/10.7208/chicago/9780226524689.001.0001

McMillion, B. J. (2017). The Blue Slip Process for U.S. Circuit and District Court Nominations: Frequently Asked Questions (pp. 1-16). Congressional Research Service: Report 2 (October).

National Labor Relations Board v. Noel Canning, 2 S. Ct. (June 26, 2014).

Owens, M. E. (2018). Changing Senate Norms: Judicial Confirmations in a Nuclear Age. PS: Political Science \& Politics, 51, 119-123. https://doi.org/10.1017/S1049096517001986

O'Connell, A. J. (2015). Shortening Agency and Judicial Vacancies through Filibuster Reform? An Examination of Confirmation Rates and Delays from 1981 to 2014. Duke Law Journal, 64, 1645-1715.

Ostiguy, P., \& Roberts, K. M. (2016). Putting Trump in Comparative Perspective: Populism and the Politicization of the Sociocultural Law. The Brown Journal of World Affairs, 23, 25-50. 
Rutkus, D. S. et al. (2014). U.S. Circuit and District Court Nominations: Analyses of Obama and Predecessors. Hauppauge, NY: Nova Science Publishers, Inc.

Senate Committee on the Judiciary (2019). Judicial Nominations. https://www.judiciary.senate.gov/nominations/judicial

Sollenberger, M. A. (2010). The Blue Slip: A Theory of Unified and Divided Government, 1979-2009. Congress \& the Presidency, 37, 125-156. https://doi.org/10.1080/07343460903394218

United States Courts (2019). Current Judicial Vacancies. https://www.uscourts.gov/judges-judgeships/judicial-vacancies/current-judicial-vacanc ies

United States Government's Publishing Office (2018) Senate Calendar Of Business Wednesday. April 11, 2018. Washington, D.C: U.S. G.P.O.

U.S. Congress Senate, Senator Chuck Grassley (2017). On the History of the Blue Slip Courtesy for Judicial Nominees. 115th Cong., 1st sess., 13 November.

U.S Constitution. Article 2, Section 2. https://www.law.cornell.edu/constitution/articleii

Wallner, J. I. (2016). The Foundations of Advice \& Consent: Original Intent \& the Judicial Filibuster. Journal of Law \& Politics, 31, 297-306.

White House, President Barack Obama (2016). President Obama Nominates Two to Serve on the United States Court of Appeals.

https://obamawhitehouse.archives.gov/the-press-office/2016/01/13/president-obama-n ominates-two-serve-united-states-court-appeals

Woolley, J., \& Peters, G. (2018). Executive Orders: Washington-Trump.

http://www.presidency.ucsb.edu/data/orders.php 